\title{
WestVirginiaUniversity
}

THE RESEARCH REPOSITORY @ WVU

West Virginia Agricultural and Forestry Experiment

Davis College of Agriculture, Natural Resources

Station Bulletins

And Design

$1-1-1965$

\section{Diseases of the iris in West Virginia and their control}

\author{
J. G. Leach
}

Edward Sumner Elliott

Follow this and additional works at: https://researchrepository.wvu.edu/ wv_agricultural_and_forestry_experiment_station_bulletins

\section{Digital Commons Citation}

Leach, J. G. and Elliott, Edward Sumner, "Diseases of the iris in West Virginia and their control" (1965). West Virginia Agricultural and Forestry Experiment Station Bulletins. 509.

https://researchrepository.wvu.edu/wv_agricultural_and_forestry_experiment_station_bulletins/473 @ WVU. It has been accepted for inclusion in West Virginia Agricultural and Forestry Experiment Station Bulletins by an authorized administrator of The Research Repository @ WVU. For more information, please contact ian.harmon@mail.wvu.edu. 
West Virginia University Libraries

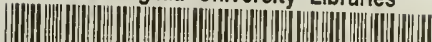

|.

308021008961379

308021008961379 
Digitized by the Internet Archive in 2010 with funding from

Lyrasis Members and Sloan Foundation 
LLETIN 509/JUNE 1965

SEASES OF THE IRIS WEST VIRGINIA AND THEIR CONTROL

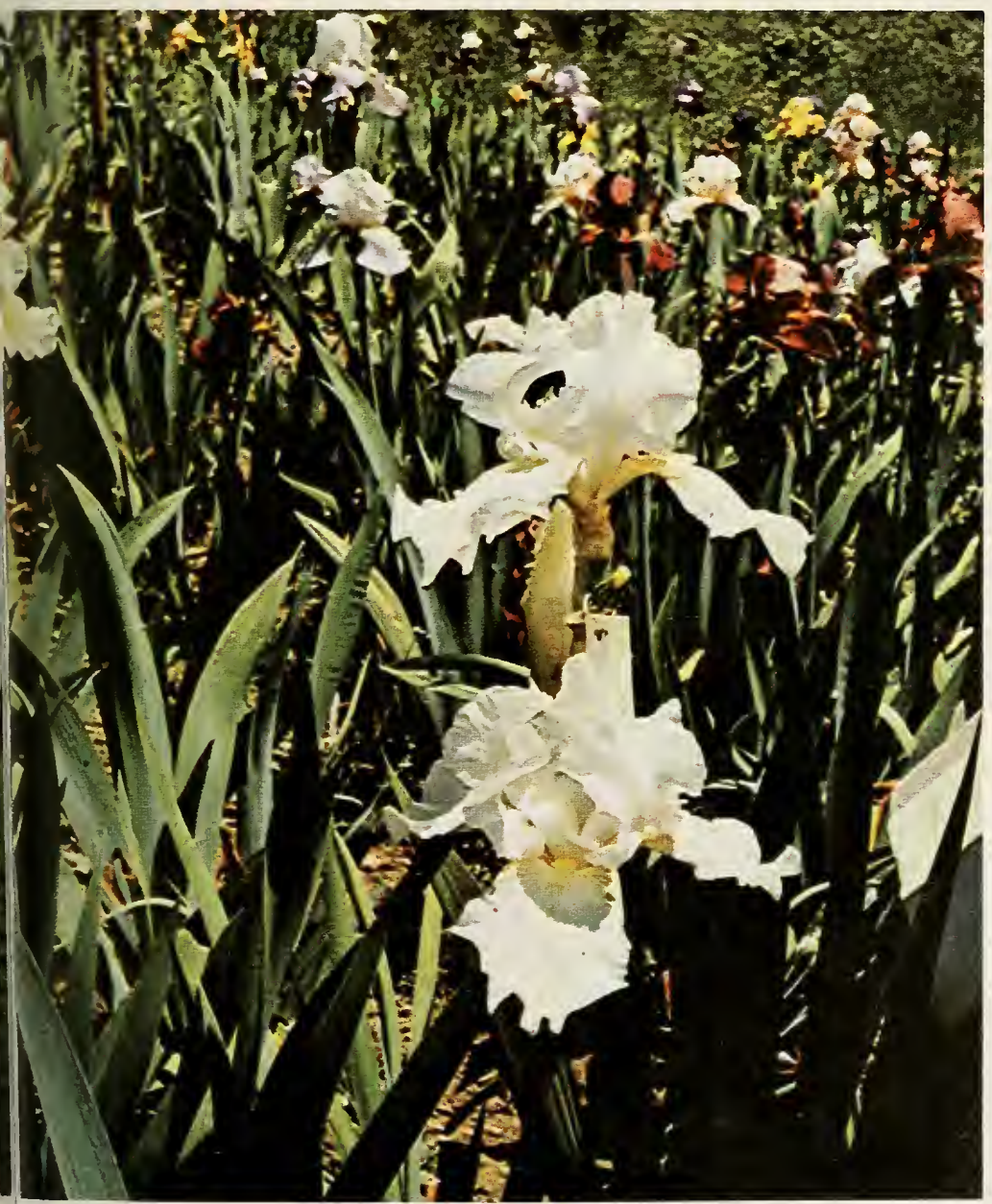

YIT VIRGINIA UNIVERSITY

II ICULTURAL EXPERIMENT STATION 


\section{THE AUTHORS}

The authors of Diseases of the Iris in West Virginia and Their Control are J. G. Leach, Station Plant Pathologist and Professor of Plant Pathology, College of Agriculture, Forestry, and Home Economics; and E. S. Elliott, Associate Station Plant Pathologist and Associate Professor of Plant Pathology, College of Agriculture, Forestry, and Home Economics.

\section{ACKNOWLEDGMENT}

The authors express their sincere appreciation to Professor Claude J. Davis for his kind cooperation throughout this study and for the color photograph used on the cover.

WEST VIRGINIA UNIVERSITY Agricultural Experiment Station

College of Agriculture, Forestry, and Home Economics A. H. VanLandingham, Director MORGANTOWN 


\section{Contents}

Page

BACTERIAL SOFT ROT _ 3

The Irus Borer ANd Soft Rot

Control Measures for the Irus Borer and the Associated Soft Rot

Bacterial Leaf Blight

Crown Rot

Botrytis Rhizome Rot

SCORCH 



\section{DISEASES OF THE IRIS \\ In West Virginia And Their Control}

\section{J. G. LEACH AND E. S. ELLIOTT}

\section{Introduction}

RISES are among the most popular flowers grown in home gardens in West Virginia. Interest stimulated by the American Iris Society and the numerous local iris societies, together with the success of professional and amateur iris breeders, promise to increase their popularity. The enthusiasm of the beginning iris grower, and sometimes that of the more experienced gardener, may be dampened by the appearance of one or more diseases to which the iris is subject. This bulletin is written to describe the most important diseases affecting the iris in West Virginia and to give directions for their effective control.

The scope of the bulletin is limited to the common bearded iris although the diseases described may occur on other kinds of irises as well. The two most common and destructive diseases affecting irises in West Virginia are bacterial soft rot and a fungus leaf spot. Both of these diseases may be very severe in neglected plantings, but they may be controlled effectively if certain measures are consistently used when needed. Since the effectiveness of a control program depends upon a clear understanding of the nature of the diseases and the factors influencing their development, these two diseases will be discussed in considerable detail, whereas only brief references will be made to diseases not reported, or doing little damage, in West Virginia.

\section{Bacterial Soft Rot}

This disease, as the name indicates, is caused by bacteria.' It produces a foul-smelling watery rot of the leaf bases, rhizomes, and flower stalks. The disease is consistently associated with the presence of the iris borer. ${ }^{2}$ It is of minor importance in the absence of the borer and

${ }^{1}$ Erwinia carotovora, a bacterium that causes a soft rot of many vegetables and ornamental plants. It is recognized as a wound parasite due to its inability to infect plants except through wounds of some sort. The foul odor associated with the disease is not caused by $E$. carotovora but by other non-pathogenic bacteria that follow it.

${ }^{2}$ Macronoctua onusta, the most destructive iris pest, whose injury is greatly increased by its influence on the development of the soft rot. 
is always severe when the borers are numerous. For this reason the control of the disease is, to a large extent, dependent upon the control of the borer.

\section{THE IRIS BORER AND SOFT ROT}

The adult iris borer is a grayish brown moth about 1 inch in length (Figure la). It flies at night and lays its eggs in late summer or early fall. It overwinters in the egg stage (Figures $1 b \& c$ ), and most of the eggs hatch in early spring as soon as the iris plants begin to grow, although a few may not hatch until weeks later. The very small young borers bore into the leaves and feed on the leaf tissue between the upper and lower epidermis in the manner of a leaf miner (Figure 2). After a short period of feeding they may emerge and re-enter the leaf lower down. They soon enter the leaf bases and eventually invade the rhizomes (Figure 3a). The leaves and rhizomes on which the borers feed soon become infected with the bacteria and develop the characteristic rot. The infected leaves, rotted at the bases, fall over and turn brown (Figure $3 \mathrm{~b}$ ). Some of the borers from late-hatched eggs may infest the flower stalks and the unopened buds. Most of the borers continue to feed on the rhizomes, increasing in size until late summer when they may be more than an inch long (Figure 4a). Towards the end of summer the large borers leave the rotting rhizomes and burrow into the soil where they transform themselves into pupae (Figure $4 \mathrm{~b}$ ). After about three weeks, when pupation is complete, the emerged moths take flight, mate, and soon thereafter the females begin to lay eggs. As soon as egg laying is completed the adult moths die. Thus only the eggs overwinter.

Although many people had observed the association of soft rot with borer infestations, no careful experimental study of the association was made until Howard and Leach' made a careful study of the borer and its role in the development of soft rot.

Since the bacterial rot first appears in the feeding wounds made by the borers it was necessary to determine how the bacteria survive the winter and the source of those bacteria that cause the first rot to appear in the spring. Since the borers overwinter in the egg stage it was possible that the bacteria could survive the winter in or on the eggs and thereby contaminate each borer as it hatched. This was not the case however, for when over-wintered eggs, some surface sterilized and some not, were hatched or crushed on nutrient agar, soft rot-bacteria were never recovered. These results indicate strongly that the soft-rot bacteria do not survive overwinter on or in the eggs of the borer. It therefore was necessary to consider other sources of primary infection. 
a
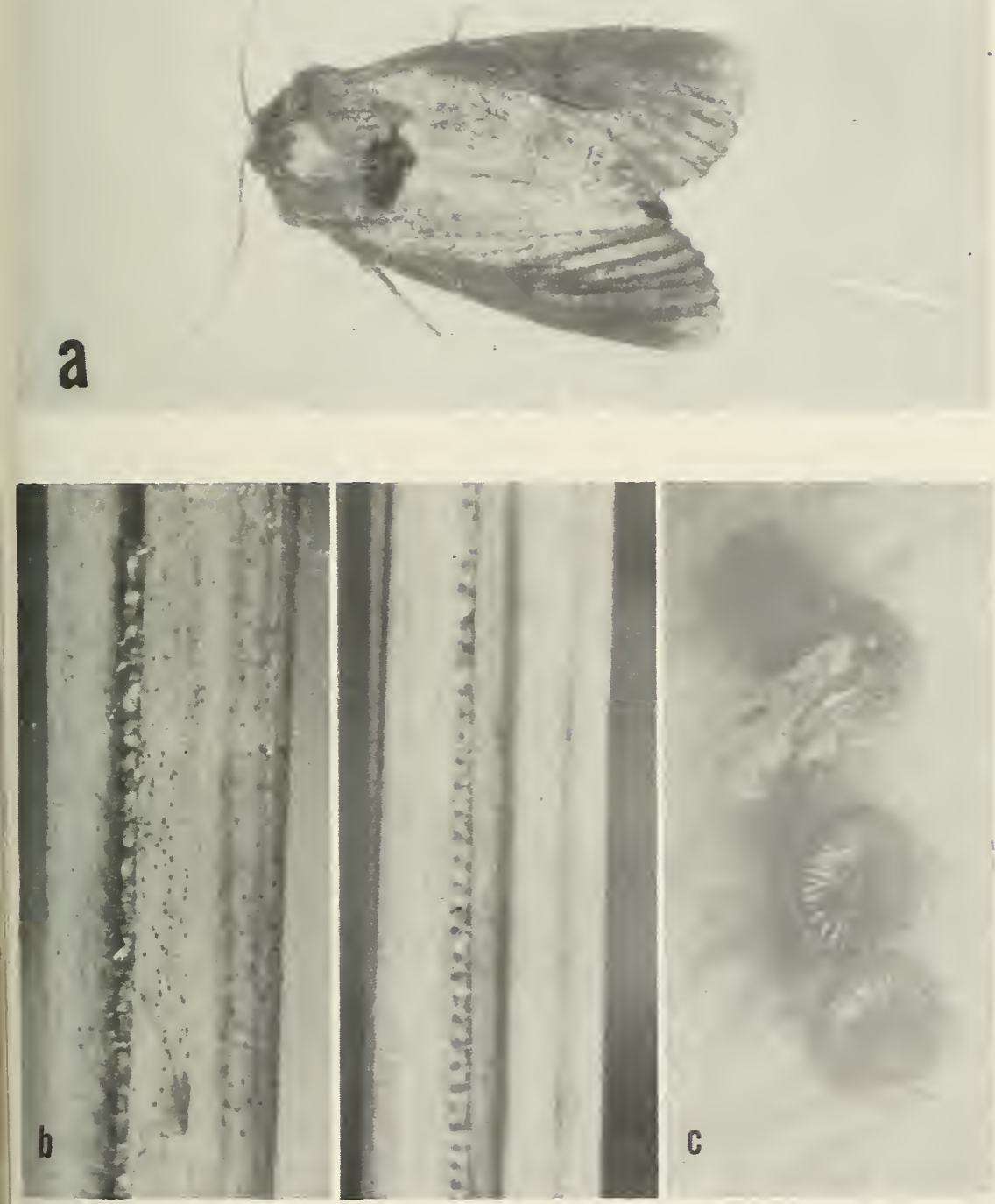

Figure 1a. A mature moth of the iris borer, about twice natural size. These moths are prevalent in late summer and early fall. They fly at night and are seldom seen.

Figure 1b. Eggs as laid by the moths in the crevices of dried flower stalks, the preferred site for ovoposition. Approximately 4X.

Figure 1c. Three borer eggs magnified approximately 25X. 


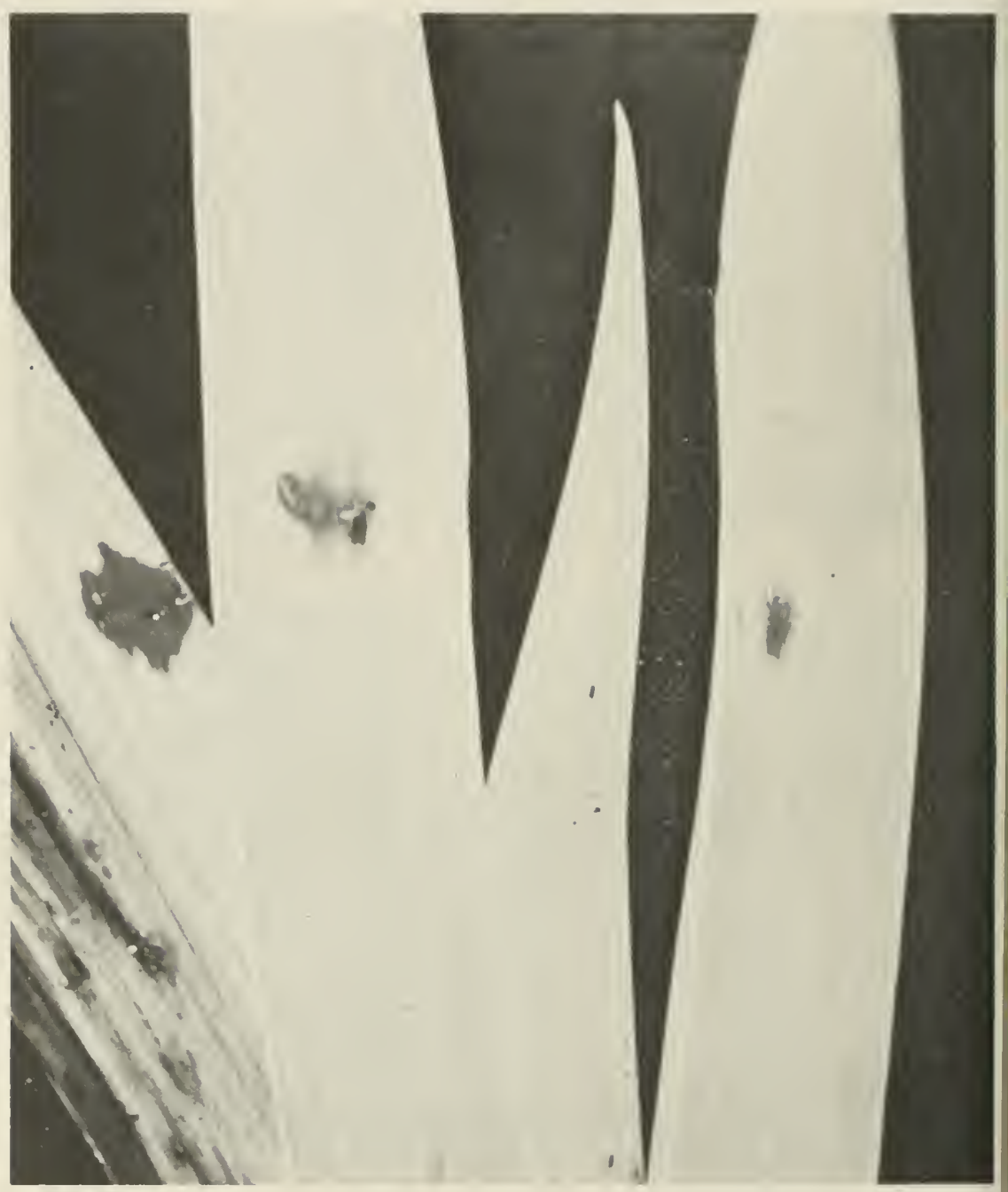

Figure 2. Water soaked spots in which young larvae are feeding as leaf miners between the upper and lower epidernis.

Extensive studies, using differential media for isolating the pathogen, showed that the soft-rot bacteria regularly survive the winter in the soil and are universally present in most cultivated soils. All experimental evidence indicates that the bacteria responsible for primary infection come from the soil and enter through the wounds made by the borer while feeding on the leaf bases. From this time on the bacteria are constantly present in the feeding tumnels made by the 


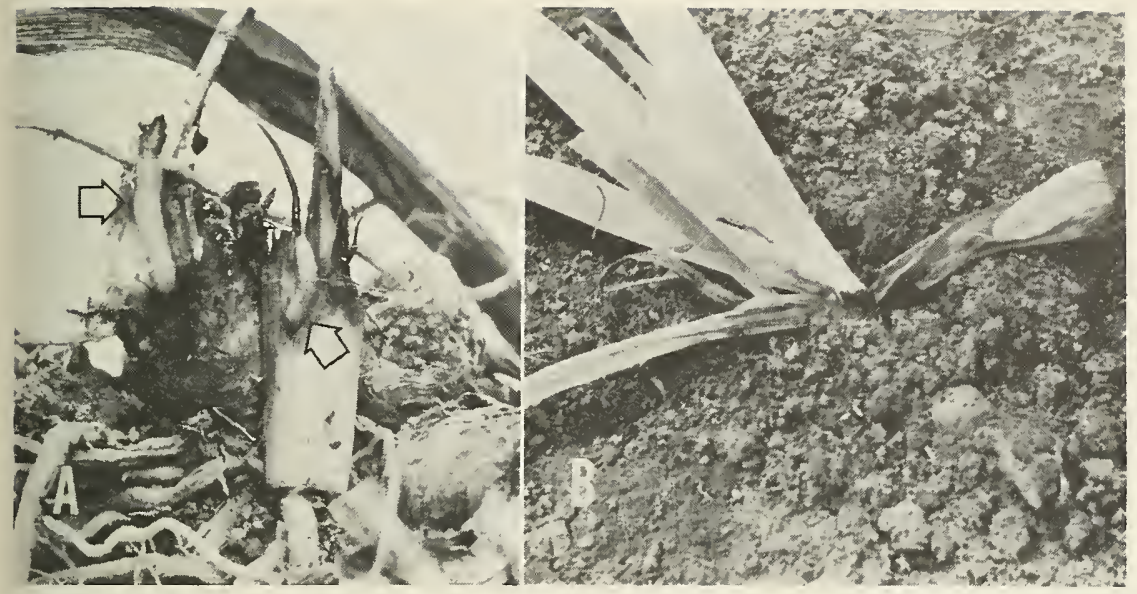

Figure 3a. A badly rotted rhizome showing two half-grown larvae feeding in rotted tissue.

Figure $3 \mathrm{~b}$. An irls plant affected with soft rot at the base of the leaves causing them to fall over.

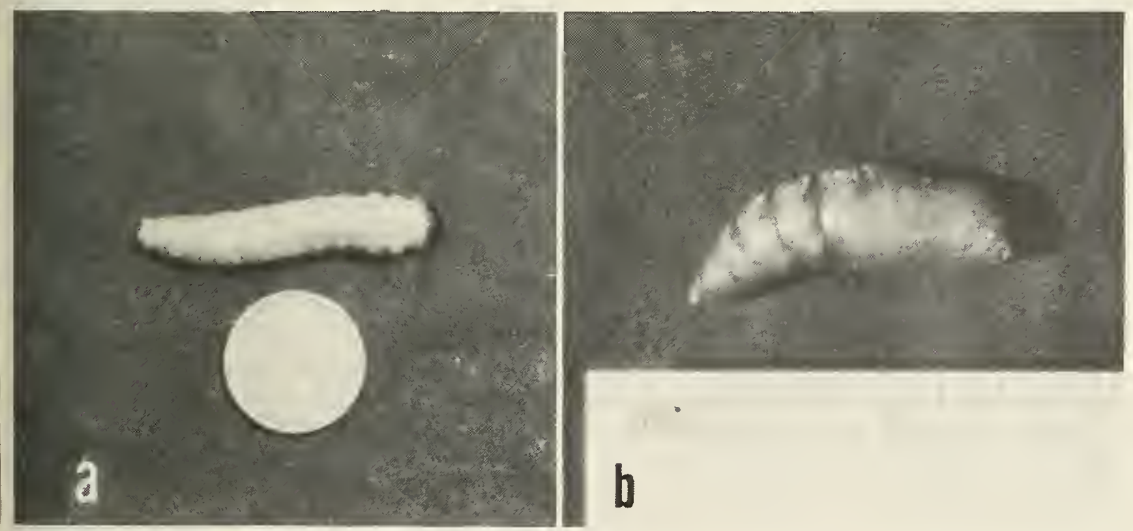

Figure 4a. A full-grown larva ready to enter the soil and pupate. Slightly reduced.

Figure $4 \mathrm{~b}$. A pupa removed from the soil. It is about ready to emerge as a moth.

developing borers. Fortunately the iris plant has, in its ability to form wound cork, a very effective means of protecting itself against the bacterial rot. When the iris rhizome is wounded mechanically, and conditions are favorable for iris growth, the wound normally heals by laying down a very thick layer of cork cells that effectively prevents the further development of the soft rot (Figure 5). This healing process makes it possible to check the rot by destroying the borers, and by cutting away infected tissue. 


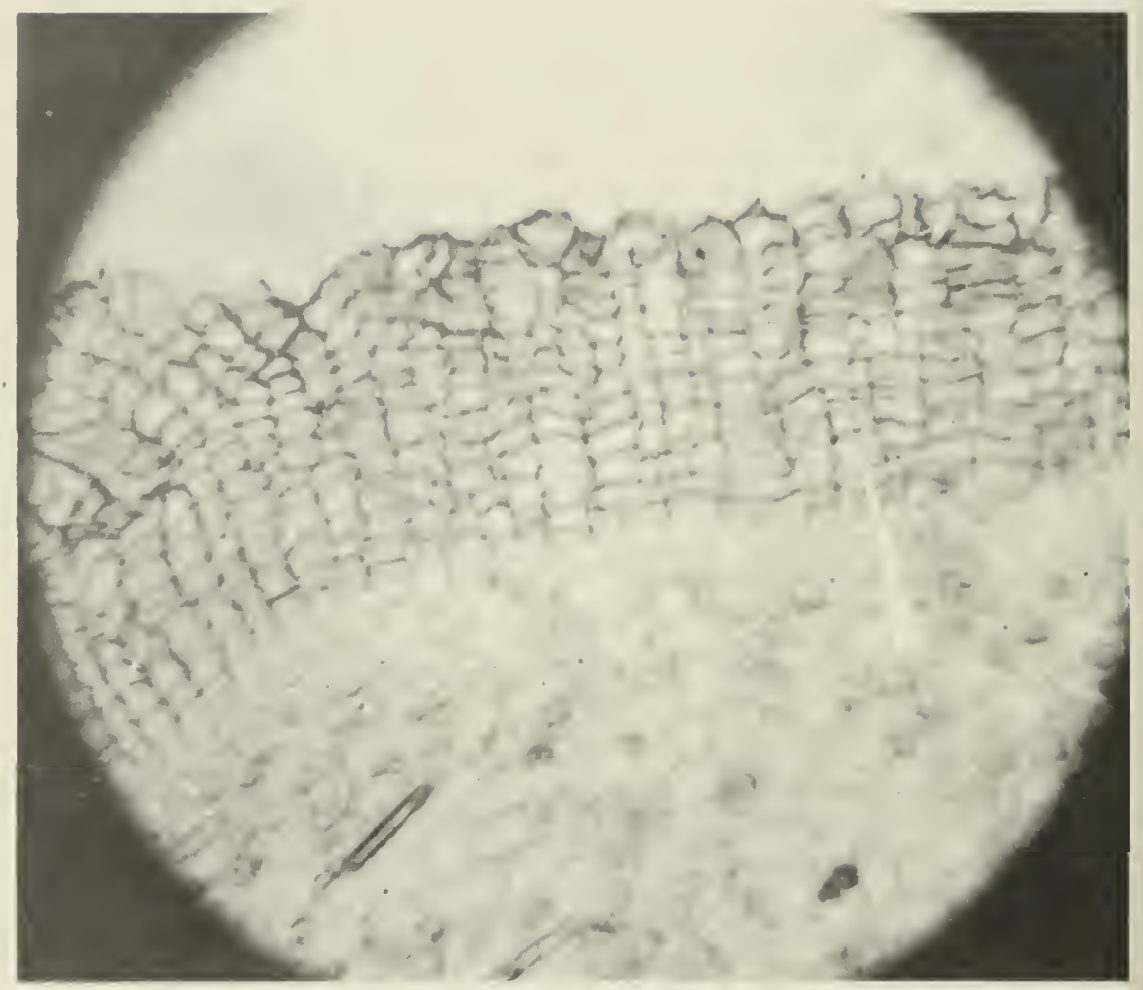

Figure 5. A section of rhizome showing the massive layer of wound cork that often checks the spread of soft rot when the borer has left the plant to pupate. Approximately 68X.

An abundant supply of oxygen is required for the formation of wound cork and if the soil is too wet the air is forced out of the soi! and decreases the oxygren available to the rhizomes. For this reason the bacterial rot is usually most difficult to control in excessively wet soils.

However, even in dry weather, if borers are present, they destroy the wound cork as fast as it is formed by the plant so that the wounds never heal and the soft rot continues to spread. On the other hand, when the borers leave the rhizomes to pupate the rot usually ceases to spread unless conditions are unfavorable for the formation of wound cork.

Those who have studied the egg-laying habits of the iris borer have usually based their conclusions on the behavior of insects in cages where the eggs are deposited on dead iris leaves or other debris. Extensive field observations by Howard and Leach' have shown that, 
in nature, the preferred sites for ovoposition are the crevises in the dried flower stalks (Figure 1b). In carefully managed plantings, the flower stalks are usually removed before the eggs are laid. In such cases the eggs are, from necessity, deposited on dead leaves or other debris. If a few flower stalks are left in or near an infested planting many of the eggs will be deposited on them; and if these stalks are collected and burned in October after eggs are laid, many eggs will be trapped and destroyed.

Each female moth lays a thousand or more eggs and most of these may hatch but only a few reach maturity. A hundred or more eggs may be deposited on a single flower stalk; even though all may hatch, rarely more than one mature borer survives in a single fan or rhizome. This is attributed to their cannibalistic nature. When two or more borers meet in a leaf or rhizome a battle ensues and the loser is consumed by the victor. This habit would greatly limit the number of infested fans from a single cluster of eggs were it not for another interesting habit of the young borers. In some experiments involving freshly hatched borers it was observed that the young borers instinctively migrated to the top of the enclosing containers regardless of light, temperature, or available food. In further studies it was noted that, as soon as the borers reached the maximum height attainable, they would spin single-strand webs, drop part way towards the ground, and remain for some time, suspended by the web. These small borers, swinging on webs, may in nature, be caught by wind currents and scattered over a wide area thereby causing more plants to be infested, and fewer borers to be destroyed by cannibalism (Figure 6 ).

Since the borers overwinter only as eggs deposited on flower stalks or, in their absence, on dead leaves or other debris, it is obvious that if such material is collected and burned in late fall, after egg laying is completed in late October, many eggs will be destroyed. If the cleanup is done earlier, before egg laying is completed, many eggs will be missed and the operation will not be effective. If the cleanup is delayed until spring it must be done early in April before the first eggs hatch.

For the most effective control where borers are numerous the plants should be lifted and divided. Each plant or fan should be examined carefully and all borers destroyed. This operation should be done in July or early August for if it is done much earlier some of the younger borers from late-hatching eggs will be so small that they will be overlooked. If done later some of the borers will have entered the soil to pupate and will be missed.

These precautions will reduce the prevalence of the borers but they are not enough to insure complete control when the borers have 


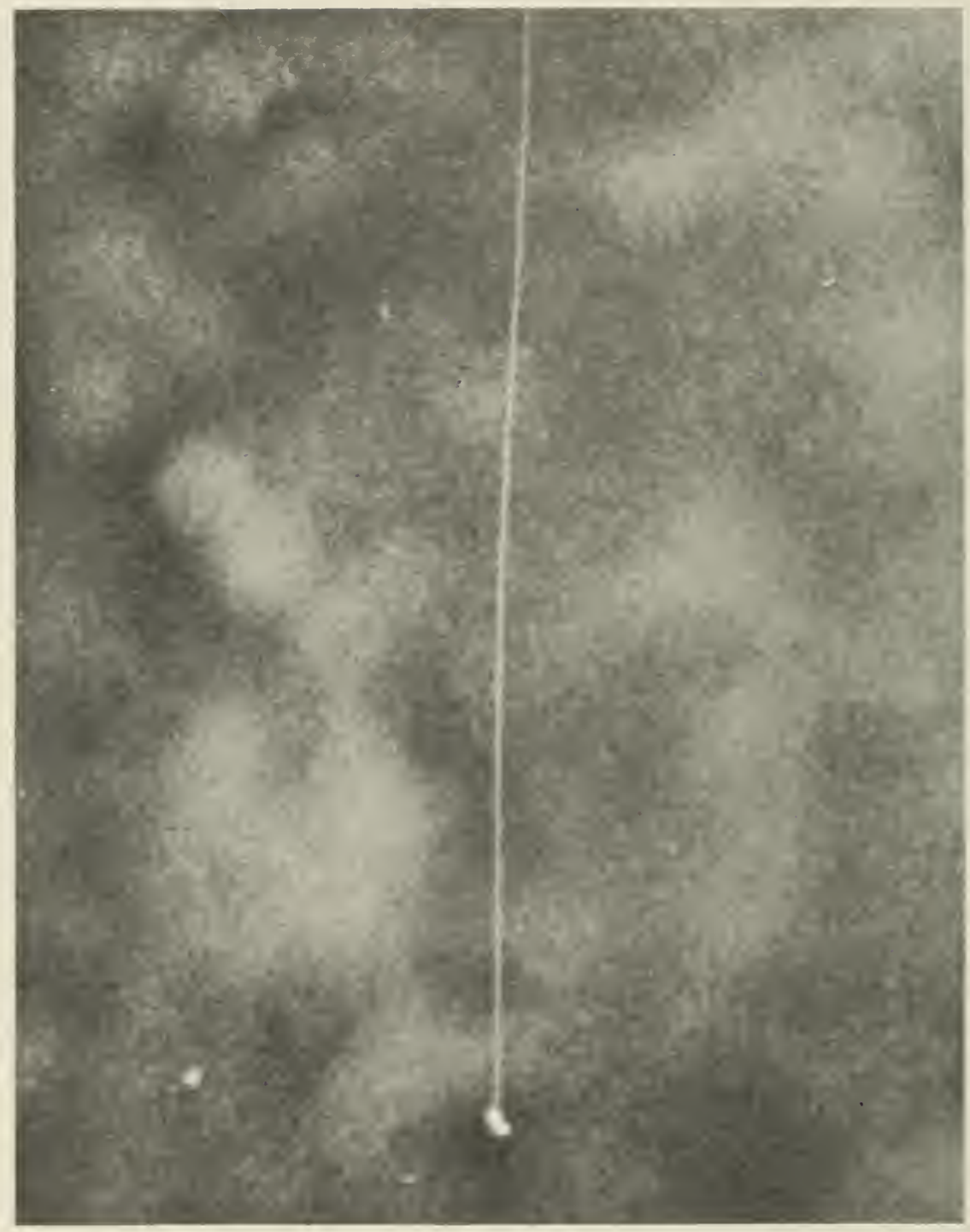

Figure 6. A young freshly hatched larva suspended on its web. Such larvae are blown for considerable distances by wind and convection currents. This is the principal way in which the insects are spread throughout a planting of irises.

become abundant. The use of an insecticide in early spring is necessary for effective control under these conditions. Several of the contact insecticides with residual action, such as DDT or Sevin, are satisfactory if used properly. The systemic insecticides Thimet and Dimethoate 
have been reported to be effective but until more information is available they are not recommended for use in the home garden. The U.S. Department of Agriculture recommends Dimethoate applied as a spray to the foliage "when infestation begins."

The time and method of application are important and because of seasonal variations in the period during which eggs may hatch insecticides with residual action are preferred.

Most directions call for spraying the plants as soon as the leaves are 6 inches high or soon after the eggs hatch. Our studies have led us to conclude that more effective control is obtained when the insecticide is applied as a dust to the soil around the plant as soon as the plants begin to grow in the spring. It is important that the insecticide be applied before the eggs begin to hatch. This may be early in April in West Virginia.

Assuming that the flower stalks have been removed the borers must hatch from eggs attached to dead leaves or other debris on the soil. The young borers must crawl over the soil for some distance to reach the plants and if the soil is heavily dusted with a contact insecticide few of them will reach a plant without coming in contact with it. Once the borer has reached an unprotected iris plant it bores into the leaf and feeds as a leaf miner on tissue not protected by an insecticide. The difficulty of wetting the surface of iris leaves and the small area of leaf surface involved in the feeding of the borers makes the usual method of protective spraying rather ineffective.

The effectiveness of the early application of an insecticide dust to the soil around the plants was demonstrated in several borer-infested gardens in the spring of 1964. As no large uniform planting of irises was available the plots were laid out in eight local home gardens whose owners were kind enough to cooperate with us.

A 5 per cent Sevin dust was used on all treated plots. It was applied to the soil surrounding the plants using a quart fruit jar with numerous aail holes punched in the metal top. Three liberal applications were nade at approximately two-week intervals, the first on April 4 before here was any evidence of hatching eggs. At each application enough lust was used to cover completely the soil between and surrounding the ndividual plants and also the exposed rhizomes and leaf bases. The econd application was made on April 21, also before the borers were zvident, but only a few days before the newly hatched borers were ibundant. A third application was made on May 2 after the young orers had made their appearance in all infested plantings. The dust ipplications were somewhat heavier than the usual applications made o plants for the control of chewing insects but greenhouse experiments 
Table 1. Control of Iris Borers By Three Heavy Applications of 5 Per Cent Sevin Dust to the Soll Around Plants in Early Spring

\begin{tabular}{|c|c|c|c|c|c|}
\hline Plot No. & Treatment & $\begin{array}{c}\text { Borer } \\
\text { infestation }\end{array}$ & Plot No. & Treatment & $\begin{array}{c}\text { Borer } \\
\text { infestation }\end{array}$ \\
\hline 1 & dusted & $0 / 42$ & 5 & dusted & $0 / 60$ \\
\hline $1 \mathrm{a}$ & not dusted & $14 / 30$ & $5 \mathrm{a}$ & not dusted & $3 / 57$ \\
\hline 2 & dusted & $0 / 40$ & 6 & dusted & $3 / 26$ \\
\hline $2 a$ & not dusted & $6 / 30$ & $6 a$ & not dusted & $8 / 32$ \\
\hline 3 & dusted & $0 / 30$ & 7 & dusted & $0 / 55$ \\
\hline $3 a$ & not dusted & $2 / 40$ & $7 a$ & not dusted & $5 / 62$ \\
\hline 4 & dusted & $1 / 22$ & 8 & dusted & $0 / 48$ \\
\hline $4 \mathrm{a}$ & not dusted & $6 / 24$ & $8 a$ & not dusted & $13 / 43$ \\
\hline
\end{tabular}

had shown that applications much heavier than those used were in no way injurious to the plants.

The control of the borers and soft rot was exceptionally good as shown by notes taken on May 17 when borers were abundant in the nontreated control plots (Table 1).

If the irises are lifted when the rot is active in the rhizomes, all rotted tissue should be cut out with a sharp knife and the rhizomes soaked in a disinfectant solution such as Semesan or mercuric chloride (1-1000) then dried in the sun before resetting. Rhizomes so treated will lay down a layer of wound cork that will check the further spread of the decay.

\section{CONTROL MEASURES FOR THE IRIS BORER AND THE ASSOCIATED SOFT ROT}

1. Examine plants frequently to detect any borers that may be present. Lift infested plants in July or early August and kill all borers present. Cut off all rhizomes infected with soft rot and soak the remaining rhizomes for 10 minutes in a disinfectant solution such as mercuric chloride (1-1000) or in Semesan for 30 minutes, then let them dry in the sun before resetting.

2. Clean up and destroy dead leaves, weeds, and other debris in the fall after November 1 when egg laving is completed. If for any reason the "cleanup" is delayed until spring it must be done in early April before the first eggs hatch.

3. If any old flower stalks are available place a few among the plants in an upright position about August 1 and let them remain there until November 1 when they should be collected and burned. This will eliminate many of the eggs that have been deposited on the old flower stalks. 
4. Dust the plants and surrounding soil, including exposed rhizomes, heavily with an insecticide such as 5 per cent Sevin, or 5 per cent DDT in early spring before the eggs hatch and at two-week intervals until blossom time.

This program, if carefully followed and consistently practiced, should free any iris planting of borers and soft rot.

\section{Leaf Spot}

A second widespread disease of iris is the fungus leaf spot caused by Didymellina macrospora Kleb. It appears on several species of iris including the bulbous types and on certain related plants but is a major problem only on the commonly grown bearded iris (Iris germanica L.). One frequently sees a browning of day lily (Hemerocallis) leaves caused by this same fungus or a closely related species.

It may seem that the small spots on the leaves do not cause much damage to the plant but when infected plants are compared with those that are disease-free, it is evident that the disease does cause premature death of the foliage and a reduction in vigor. When infection is heavy, rhizome growth is reduced and the plant becomes more subject to cold damage and to other similar types of injury.

The spots may vary considerably in size (Figure 7). They begin as green, water-soaked areas which soon become brown and dry. Usually a ring of darker brown cells surround the lighter colored, dry centers.

Premature death of the leaves prevents the normal growth of rhizomes and plants have less vigor the following season. Although the disease may indirectly cause the death of plants, it usually results only in unthrifty plants.

Occasionally a black, velvety mass of fungus spores is seen on the surface of the dried spot. These are the Heterosporium spores of the asexual stage of the fungus. These spores are responsible for repeated infection cycles during the growing season. They are spread mainly by rain to other locations on the leaf, or to other leaves. There the spores germinate and, if weather conditions remain favorable, the fungus penetrates the leaf and grows, utilizing the contents of the plant cell as food. Within a few days a water-soaked spot outlines the invaded area in the iris leaf.

This leaf spot is particularly severe in regions subject to frequent extended periods of rainfall and the accompanying high humidity.

The fungus lives through the winter on dead leaves that it invaded the previous summer. In warm spring weather, masses of the Heterosporium spores are produced on the old infected leaves. These start the disease again when the spores are splashed to the new foliage. 


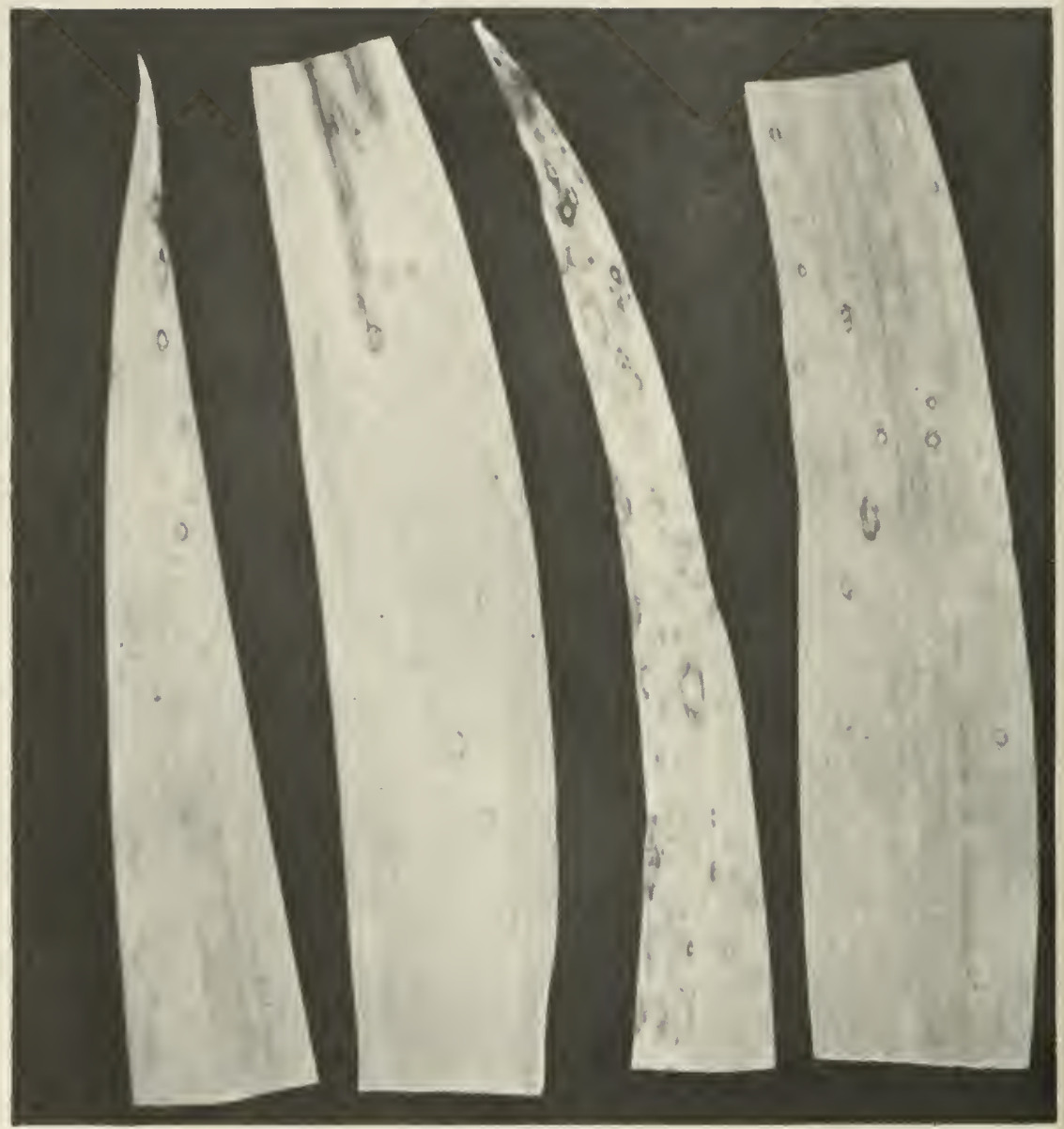

Figure 7. Leaf spots caused by the fungus, Didymellina macrospora in various stages of development on leaves of the bearded iris. Note the characteristic dark margins of the older spots that are not present on spots caused by bacteria.

Repeated observations on material from various sections of West Virginia indicate that the sexual Didymellina stage with its air-borne spores occurs only rarely and that initial spring infection is brought about chiefly by renewed growth of the fungus and production of the Heterosporium spores which are spread primarily by splashing rain. This observation may be of some importance when control measures are considered. It indicates the importance of eliminating dead, overwintering iris foliage since a major part of the spores causing spring infections will be water splashed from this source. 


\section{Leaf Spot Control}

The iris grower may combat this disease by two methods, (a) by collecting and burning diseased plant material, and (b) by application of suitable fungicides. Either method alone may not check the disease adequately but when both are properly used, excellent control can be obtained.

Tisdale (2) showed that removal of dead infected leaves before new. growth had commenced in the spring checked the spread of the disease during the early spring season. In more recent years, removal of diseased leaves at any time that they may appear in quantity has been a standard practice in disease control. Particular care should be taken to remove all dead or living infected leaves when clumps are divided.

In areas where the iris borer and the accompanying soft rot are a problem and it is desirable to leave the old flower stalks to attract the egg-laying moths, the stalks must be removed and burned before growth starts in the spring.

If the grower wishes to obtain. maximum control of leaf spot, it is necessary to protect the plants with suitable fungicides throughout the growing season. These materials may be applied either as sprays or dusts. Dusts are easier to apply,.. but, in general, they are somewhat less effective than sprays. Since iris leaves have a very waxy surface and generally stand in an erect position, it is more difficult to get good spray coverage than on other kinds of plants having less waxy leaves oriented in a horizontal position. Certain commercial wetting agents are generally available wherever pesticides are sold and should be added to spray solutions for use on plant species that are difficult to wet. These commercial wetting agents are much more effective than household detergents which may frequently be substituted for them in spraying less waxy leaves. Any wetting agent should be added to the spray solution in the least amount necessary to obtain good wetting.

A limited testing program carried out in 1960 indicated that some commonly available materials will control this disease effectively. Three organic fungicides, Zineb (75 WP), Maneb (70 WP), and Phaltan (50 WP), were compared in this test. The first two listed were used at the rate of 1 level tablespoon of the wettable powder per gallon of water; Phaltan was used at 1/2 level tablespoons per gallon. These three fungicides were about equally effective in controlling the disease. Another fungicide found effective elsewhere is Captan (50 WP); it was not included in the trials at this station. 
Weekly applications of a fungicide beginning with the first leaf growth in the spring and continuing through the season until cold weather checks growth, will give excellent leaf-spot control. During the hot, dry weather of midsummer, less frequent sprays will suffice. Application of the fungicide until after the blossom period gives adequate early season control but if stopped then, late-season development of the disease will provide greater amounts of the fungus to cause trouble the following season. Nearly complete control obtained in one season will result in less disease the following season. In other words, the benefits of good, continuing control practices will be cumulative and increasingly effective.

\section{Other Iris Diseases in West Virginia}

Except for the two diseases described in some detail, there are few iris disease problems in West Virginia. A number of other diseases do occur in the eastern United States and these may occasionally be encountered here. A brief description of these and methods of control follows.

\section{BACTERIAL LEAF BLIGHT}

A bacterial disease caused by Xanthomonas tardicrescens closely resembles the widespread Didymellina leaf spot. Perhaps the close resemblance may have caused leaf blight to be overlooked. The dark border typical of the fungus leaf spot is not present. A mass of bacteria may exude from the infected areas. In wet weather these are sticky droplets; when dry they appear as varnish-like scales.

Destroying diseased material by burning is the best proven method of control of bacterial leaf spot. Antibiotic sprays which are effective against many bacterial plant pathogens may prove suitable but have not been tested adequately.

\section{CROWN ROT}

The fungus Sclerotium rolfsii may cause a rotting of the leaf base at the soil line. Indications of the presence of crown rot are browning of leaf tips, rotting of leaf bases and small, brown sclerotial bodies associated with a white fungus growth around the rotting base. Rhizomes do not rot.

Since the disease is favored by wet soils, adequate drainage gives some degree of control. Various concentrations of Terraclor have been suggested as a soil drench treatment. (One tablespoon of the 75 per cent 
wettable powder per gallon of water applied at the rate of 1 pint per square foot may be adequate. )

\section{BOTRYTIS RHIZOME ROT}

A species of Botrytis causes a rot of rhizomes during the winter and spring. It may be recognized by the decayed rhizome, the weak, yellow new shoots, and the presence of many small, black, irregular sclerotial bodies attached to the rotted rhizome and roots.

Avoid replanting in contaminated soil after diseased plants are removed. Pretreating divisions with mercuric chloride or Semesan before planting as suggested for control of bacterial soft rot gives some degree of control.

\section{SCORCH}

A disease of unknown cause called scorch is occasionally encountered in West Virginia. It may be recognized by the dying back of leaves beginning with the tip of the newest leaf. The dying leaf tissue is of a distinctive brown color. Browning progresses back through the leaves of the fan until all are dead. A similar death of root tissue occurs at the same time. The dead fans do not pull away from the rhizome as would occur in bacterial soft rot or crown rot. A number of causes have been suggested but none of these have been proven. Eliminate these plants as soon as the disease is observed. No other control measures can be suggested.

\section{Iris Disease Control Summary}

The following practices are generally recognized as useful in controlling diseases of bearded iris.

1. Plant in well-drained, sunny locations. Areas with previous iris disease history should be avoided. Do not place the rhizomes too deep, only the roots need to be covered.

2. Treat rhizomes with mercuric chloride or other similar materials before planting.

3. Maintain vigorous growth by applying adequate fertilizer, preferably in the spring.

4. Divide and replant at three- or four-year intervals to avoid crowding.

5. Do not allow plantings to become overgrown with weeds.

6. Treat with the required fungicides or insecticides to control specific diseases or insect pests. 
7. To aid in the control of leaf spots remove and burn dead or infected leaves at frequent intcrvals throughout the year. 'To control the borers and soft rot more effectively the clean up should be done in late October or November after the borers have completed their egg laying. It is very important to remove and destroy any flower stalks still present at this time.

8. Dust the plants and surrounding soil with 5 per cent DDT or Sevin as described on page 11 .

\section{Literature Cited}

1. Howard, Charles M., and J. G. Leach. 1963. Relation of the iris borer to bacterial soft rot of iris. Phytopathology 53: 1190-1193.

2. Tisdale, WV. B. 1920. Iris leaf spot caused by Didymellina iriclis. Phytopathology 10: 148-163. 

